\title{
Urban Temperature Analysis and Impact on the Building Cooling Energy Performances: An Italian Case Study
}

\author{
Michele Zinzi ${ }^{1}$, Carlo Romeo ${ }^{1}$, Emiliano Carnielo ${ }^{2}$, Alessandro Mangione ${ }^{3}$ \\ ${ }^{1}$ Energy Efficiency in Buildings Unit, ENEA, Rome, Italy \\ 2 Department of Engineering, University of Rome Tre, Rome, Italy \\ ${ }^{3}$ Architect, Rome, Italy. \\ michele.zinzi@enea.it
}

\begin{abstract}
The heat island effect in urban environments, (whatever the size and the latitude determining the effect intensity) is dramatically increasing due to climate changes and urban sprawl. The urban heat island is a phenomenon observed since the last decades of the XIX century, but diffused to a large scale only one century later. It is characterised by the increase of air temperature in densely built urban environments with respect to nearby natural landscape areas. Many available studies show urban heat island intensities up to $12^{\circ} \mathrm{C}$. This thermal stress causes social, health and environmental hazards, with major impacts on weak social classes, such as elderly and low income people. This study presents first results of air temperature monitoring campaigns in different neighbourhoods of Rome, a metropolitan area characterised by a typical Mediterranean climate and by a complex urban texture, in which densely built areas and green or not-built zones border one another. Six spots were monitored since June 2014; they include: historical city centre, semi-central zones with different construction typologies, and surrounding areas with various urban and building contexts. This paper explores the summer temperature profiles within the city and their increase respect to suburban areas' values. UHI intensities up to $10^{\circ} \mathrm{C}$ were monitored as well as monthly $\mathrm{UHI}$ up to $3.4^{\circ} \mathrm{C}$ in the hottest area of the city. The impact on the cooling performance and the thermal response of reference buildings were also assessed. Temperature datasets and the reference building model were inputted into adynamic calibrated calculation software. In addition, cooling net energy demand of the reference building as well as operative temperature fluctuation in the not cooled building configuration were calculated. The results of calculation allow to compare the energy and thermal performances in the urban environment with respect to the reference conditions, being the latter typically adopted by national building codes. 50 and
\end{abstract}

$100 \%$ relative increasing of cooling demand were calculated, respectively, for insulated and not insulated buildings.

Keywords - Urban temperature; building cooling energy performances; thermal comfort.

\section{INTRODUCTION}

Climate change is probably the most relevant challenge at planetary level in the coming years. Climate change is proved by scientific observations and predictions since years [1]. The global warming is strictly linked to climate change, which is occurring at all latitudes, although in different modes and intensities. The Mediterranean area is deeply interested in this phenomenon and several studies predict air temperature rise above $2^{\circ} \mathrm{C}$ in absence of adequate mitigation policies. It isimportant noting that the increase of average temperatures is not the only effect since the increase of extreme phenomena as heat waves and hot spells is also documented [2].

This area is also undergoing an urbanisation process since decades. This is again a global process, but particularly critical for Europe and the Mediterranean area, where the urbanisation increased from 54 to $66 \%$ during the years between 1970 and 2010. More than 300 million inhabitants lived in urban areas in 2010, while the figure was 150 million in 1970 [3].

The combined effect of global warming and urban sprawl is the cause of the Urban Heat Island (UHI) effect, which is defined as the increase of the air temperature in urban areas compared to that in the countryside, adjacent to the city. It can be referred to instantaneous values ( $\mathrm{UHI}$ intensity) or to average values related to different time steps (from hourly to seasonal).

The phenomenon is physically observed since the 19th century [4], but it has been extensively studied 
only since few decades, when the above illustrated causes made it clearly evident [5, 6, 7, 8]. Many studies are now available showing the $\mathrm{UHI}$ is observed at every latitude and the main factors are: green permeable areas reduction; the decrease of radiative heat loss due to the canyon effect; increase of thermal storage in buildings; anthropogenic heat released by buildings and transport systems; evaporative cooling reduction; high shortwave absorption due to low albedo materials used for buildings and pavements; solar radiation trapped under the canopy, favoured by masking and shadowing.

The UHI has several implications at environmental, social, economic and energy levels. This paper deals with the last mentioned topic, being the relation between urban heat island and energy issues the most relevant among those investigated in several studies $[9,10,11,12]$. The study discusses several themes, namely the impact of urban temperatures on the building energy and peak demands for cooling; the impact on thermal comfort and potential passive cooling technique such as the use of materials, technologies and strategies to mitigate the urban heat island and to improve the thermal response of buildings.

\section{OBJECTIVE AND METHOD}

This paper analyses the air temperature distribution within the city of Rome (Italy) and provides first data about its impact on the energy and thermal response of residential buildings. The main objective of the present study is to provide an initial assessment of urban temperatures' impact on summer energy performance of buildings highlighting the potential discrepancies between the official weather data set, generally derived from measurements taken outside the city, and the effective thermal conditions registered in urban areas.

The extension of the urban area of Rome is about $1,287 \mathrm{~km} 2$ with 2.87 million of inhabitants which could reach nearly 4 million considering the whole metropolitan area. This urban pattern is very articulated: densely built zones alternate to un-built and green areas. Furthermore, building stock's characteristics are extremely variegated in terms of urban lay-out; geometry, size, construction technologies and more.

For this study six zones are selected and their thermal response is compared to an undisturbed reference station (the ENEA research centre) located in the countryside, $25 \mathrm{~km}$ north of the city centre. The selected zones are the following:

- Z1 Historical city centre. A densely built area with Middle Ages massive buildings (height between 12-20 meters) characterised by mainly narrow streets (up to 10 meters), no vegetation, except few gardens belonging to historical mansions, and dark stone urban paving.

- Z2 Prati district. A central area, built in the late 19th century. It is characterised by massive courtyard buildings, 25 meters high on large treelined streets in asphalt, which creates a regular grid. The area is close to the Tevere river.

- Z3 Monteverde district. Dates back to the early 20th century. This area is densely built and characterised by small apartment blocks and narrow asphalt streets (8-10 meters), few green areas, mainly private gardens adjacent to the buildings.

- Z4 Ostiense district. Built in different periods, it is characterised by high buildings (30 meters) along a 60 meter wide boulevard with trees in the middle. The area is also characterised by large empty urban spaces, mainly covered with asphalt (e.g. parking lots).

- Z5 Tuscolana district. A semi-peripheral area developed in the ' 50 s and ' 60 s with linear and tower buildings between 20 and 30 meters high. It presents a wide main street and 10-12 wide lateral roads. The neighbourhood is surrounded by some green areas, but the district itself has negligible vegetation inside.

- Z6 Torrevecchia district. A peripheral area built in the '40s which mainly consists of small apartment blocks (3-5 floors). It is an articulated neighbourhood, with asphalted streets of different width and characterised by extensive green areas.

- Different urban textures of the city can be inferred by the aerial views of Zone 1 and 6 reported in Figures 1 and 2.

Air temperature and relative humidity have been continuously measured in the seven stations in order to identify the thermal stress within the selected zones respect to the undisturbed station allowing to quantify the impact of the city in term of temperature rise. 


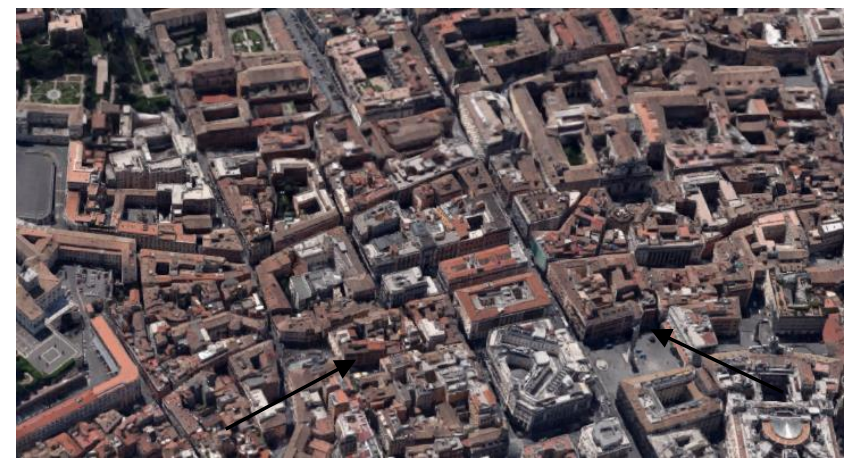

Fig .1. Aerial view of Zone 1

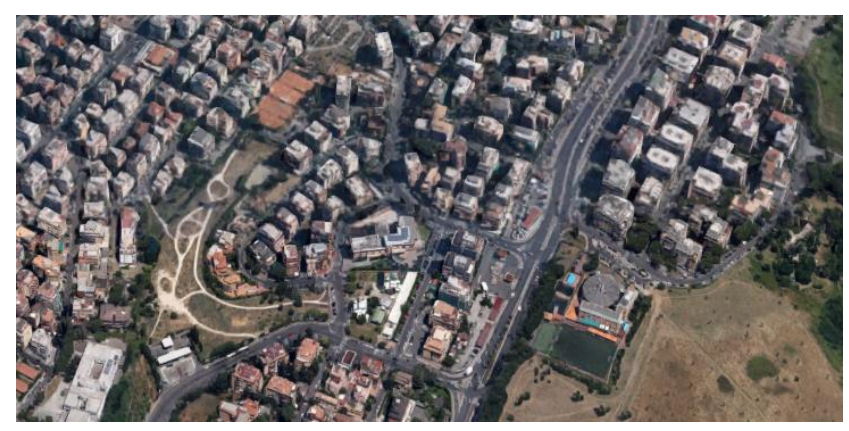

Fig .2. Aerial view of Zone 6

In the next step the measured climatic data are used as input to calculate the thermal response of a reference residential building under two operative conditions:

- Energy performance of the building equipped with a mechanical cooling system. The net energy demand is calculated, assuming an ideal energy system characterised by unlimited power, in order to focus the performance on the building structure response;

- Thermal comfort of the building in free-floating conditions, meaning that no mechanical cooling system is installed. The results allow quantifying the impact of urban heat island and associated temperature profile on the building thermal response.

\section{MONITORING CAMPAIGN}

The monitoring campaign started in June 2014 and it is still going on, since the objective is to have robust data files, able to describe the thermal response of the city across a significant period (e.g. 2 years). The seven stations are installed at 4-6 meters high from the ground level and under the canopy. They consist of a self-standing data logger and a sensor set exposed to solar radiation. The relevant sensor data are:
- ${ }^{\circ} \mathrm{C}$ temperature resolution in the $40-82^{\circ} \mathrm{C}$ range;

- $\pm 0.5^{\circ} \mathrm{C}$ maximum temperature error in the $-5-60$ ${ }^{\circ} \mathrm{C}$ range;

- $0.1 \%$ humidity resolution in the $0-100 \%$ range;

- $\pm 5 \%$ maximum humidity error in the $10-100 \%$ range.

Data are acquired every 10 minutes and averaged on 1 hour time steps for evaluations and calculations. This study is based on the data collected from July 1 st to September 20th, covering most of the 2014 cooling season.

\section{CALCULATION}

The numerical analysis was carried out using TRNSYS, a well-known and calibrated tool, able to dynamically model the thermal behaviour of buildings [15]. The software operates by means of hourly energy balance of the thermal zones. The TRNSYS model implemented for this analysis consists of subroutines, called types, to which the whole calculation phase is assigned. The reference building used for the study purpose is a three storeys block with two apartments on each floor. Each apartment has three external façades and the main geometric characteristics are the following: net floor area $89 \mathrm{~m} 2$, net volume $240 \mathrm{~m} 3$, and windows area $10.5 \mathrm{~m} 2$.

Two configurations are investigated with and without thermal insulation. $U$-values of the building components are summarised in Table I; internal gains are set to $5 \mathrm{~W} / \mathrm{m} 2$. For the energy assessment an external shading of 0.4 is assumed for windows and the air exchange rate is set to $0.3 \mathrm{ACH}$. The net cooling energy demand is calculated considering an ideal energy system working continuously. Set-points are $26{ }^{\circ} \mathrm{C}$ for the air temperature and $60 \%$ for the relative humidity. For the free floating analysis an external shading factor of 0.7 is assumed for windows and the air exchange is set to $0.5 \mathrm{ACH}$ during daytime and 2 during night-time. These assumptions derive from conscious user behaviour in not cooled buildings.

Table 1. U-VALUES OF BUILDING COMPONENTS

\begin{tabular}{|c|c|c|c|c|}
\hline $\begin{array}{c}\text { Building } \\
\text { configuration }\end{array}$ & $\begin{array}{c}\text { U-roofs } \\
{\left[\mathrm{W} / \mathrm{m}^{2} \mathrm{~K}\right]}\end{array}$ & $\begin{array}{c}\text { U-wall } \\
{\left[\mathrm{W} / \mathrm{m}^{2} \mathrm{~K}\right]}\end{array}$ & $\begin{array}{c}\text { U-ground } \\
{\left[\mathrm{W} / \mathrm{m}^{2} \mathrm{~K}\right]}\end{array}$ & $\begin{array}{c}\text { U-window } \\
{\left[\mathrm{W} / \mathrm{m}^{2} \mathrm{~K}\right]}\end{array}$ \\
\hline Not insulated & 1.1 & 1.1 & 1.2 & 5.8 \\
\hline Insulated & 0.38 & 0.4 & 0.5 & 2.8 \\
\hline \multicolumn{5}{|r}{ V. RESULTS }
\end{tabular}

The results refer to the monitoring campaign of the 
urban temperature and to the simulations, carried out to estimate the impact of temperature increase on the energy and thermal performance of the reference building.

\section{A. Urban temperature profiles}

The results show that the temperatures in the cities are higher than in the reference station. Table II reports the $\mathrm{UHI}$ values monthly averaged throughout the whole period of investigation for the 6 monitored zones. The most affected districts by the phenomenon revealed not necessarily the most central ones. Z5 is a semi-peripheral but a heavily built area and this makes it the most $\mathrm{UHI}$ affected in the city, with $3.2^{\circ} \mathrm{C}$ during the whole period. Z1 and Z4, similarly to Z5, but not with the same density, show UHI values of 2.4 ${ }^{\circ} \mathrm{C}$ and $2.2^{\circ} \mathrm{C}$ respectively. $\mathrm{Z} 2$ and $\mathrm{Z3}$ represent two heavily built central areas, where the presence of the river nearby (for Z2) and trees along the streets partially mitigate the climate: $\mathrm{UHI}$ is slightly lower than $2^{\circ} \mathrm{C}$. Z6 is similar to Z3 as construction typology but, being more peripheral, is the least affected by UHI $\left(1.5^{\circ} \mathrm{C}\right)$ among all the monitored zones. It is worth mentioning that the results are mitigated by the September climate during the peak month, namely August, the monthly $\mathrm{UHI}$ is between 0.1 and $0.2^{\circ} \mathrm{C}$ higher than the UHI values averaged over the period.

Hourly data analysis provides even more detailed information. The UHI measured intensities for the six zones are in order: $7.9,6.6,6.5,7.0,9.9$ and $6.0^{\circ} \mathrm{C}$.

These data provide an impressive measure of the impact of the built urban environment on the thermal profiles of the city. It is also worth mentioning that cool island effects are measured in all the zones, even if they are limited in the number of hours (only few hours of the morning) and in intensity so as to be considered irrelevant. Typical variations of the $\mathrm{UHI}$ are plotted in figure 3 , where the values refer to four days in August. Peak values reach $4{ }^{\circ} \mathrm{C}$ in all the zones and, in some cases, $5^{\circ} \mathrm{C}$ can be observed. The data show a more intense UHI during night time. Table III shows an extended set of the cumulative distribution of the UHI exceeding some reference values (from 2 to $5{ }^{\circ} \mathrm{C}$ ). In $\mathrm{Z} 5$ the $\mathrm{UHI}$ is higher than 3 and $5{ }^{\circ} \mathrm{C}$ respectively during the $50 \%$ and $15 \%$ of the monitoring period, confirming this area as the hottest of the city. Z1 and Z4 present similar results: the hourly UHI exceeding 2 and $3{ }^{\circ} \mathrm{C}$ for about the $60 \%$ and $30 \%$ of the total hours, respectively. For the remaining zones, a $\mathrm{UHI}$ above $3^{\circ} \mathrm{C}$ is measured for $10 \%$ and $20 \%$ of the monitored period.

Table 2. MONTHLY AND PERIOD UHI VALUES IN MONITORED ZONES

\begin{tabular}{|c|c|c|c|c|c|c|}
\hline Month & $\begin{array}{c}\mathrm{Z1} \mathrm{UHI} \\
{\left[{ }^{\circ} \mathrm{C}\right]}\end{array}$ & $\begin{array}{c}\mathrm{Z2} \mathrm{UHI} \\
{\left[{ }^{\circ} \mathrm{C}\right]}\end{array}$ & $\begin{array}{c}\mathrm{Z3} \mathrm{UHI} \\
{\left[{ }^{\circ} \mathrm{C}\right]}\end{array}$ & $\begin{array}{c}\mathrm{Z4} \mathrm{UHI} \\
{\left[{ }^{\circ} \mathrm{C}\right]}\end{array}$ & $\begin{array}{c}\mathrm{Z} 5 \mathrm{UHI} \\
{\left[{ }^{\circ} \mathrm{C}\right]}\end{array}$ & $\begin{array}{c}\mathrm{Z} 6 \mathrm{UHI} \\
{\left[{ }^{\circ} \mathrm{C}\right]}\end{array}$ \\
\hline Jul. & 2.5 & 1.6 & 2.0 & 2.2 & 3.1 & 1.5 \\
\hline Aug. & 2.6 & 1.8 & 2.0 & 2.3 & 3.4 & 1.6 \\
\hline Sep. & 1.9 & 1.5 & 1.5 & 2.0 & 2.8 & 1.3 \\
\hline Period & $\mathbf{2 . 4}$ & $\mathbf{1 . 7}$ & $\mathbf{1 . 9}$ & $\mathbf{2 . 2}$ & $\mathbf{3 . 2}$ & $\mathbf{1 . 5}$ \\
\hline
\end{tabular}

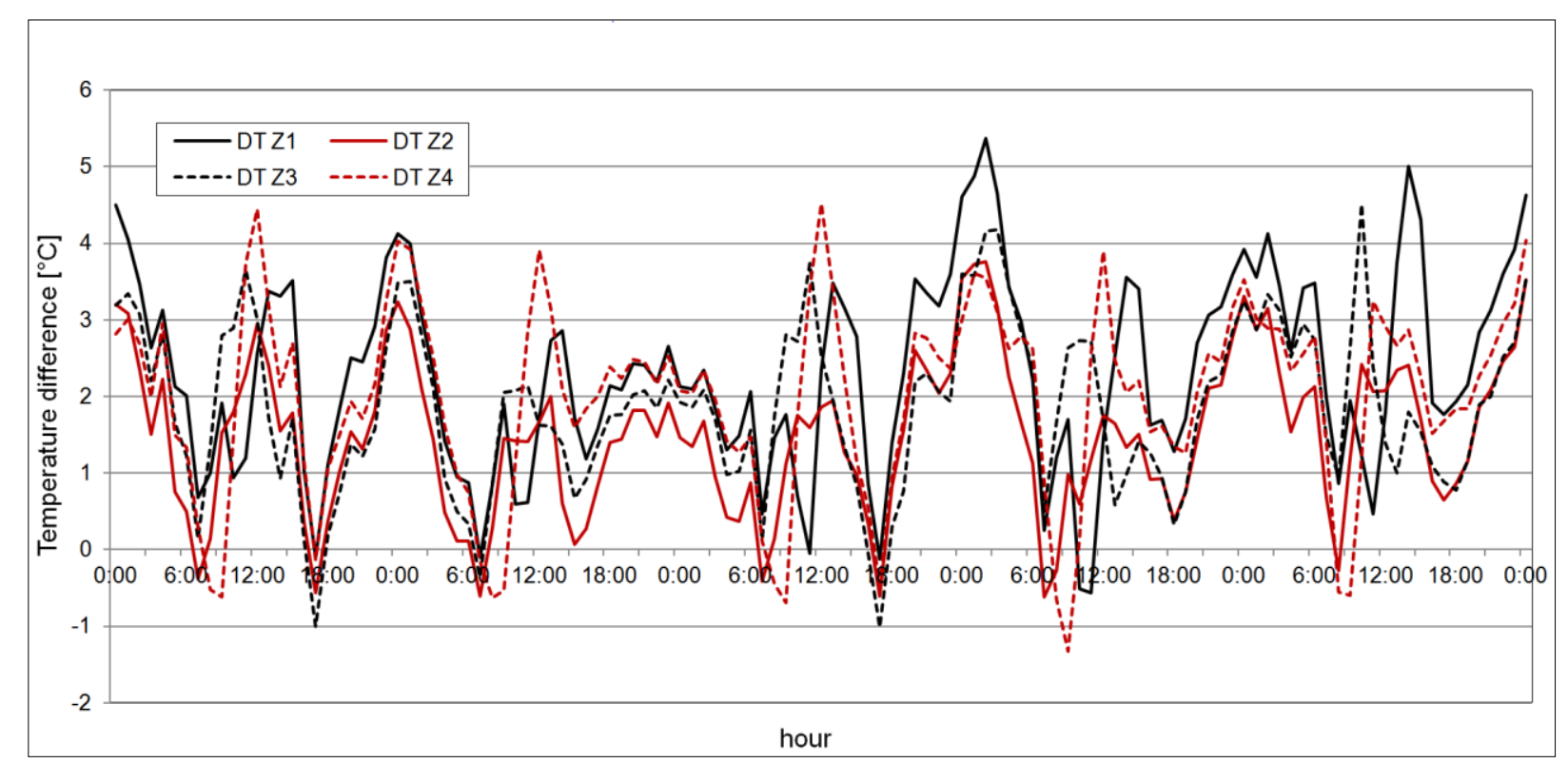

Fig .3. UHI for selected zones during 4 days in August 
Table 3. HOURS OCCURRENCE OF UHI FOR THE MONITORED ZONES

\begin{tabular}{|c|c|c|c|c|c|c|}
\hline $\begin{array}{c}\text { Temp. } \\
{\left[{ }^{\circ} \mathrm{C}\right]}\end{array}$ & $\begin{array}{c}\mathrm{Z1} \mathrm{UHI} \\
{\left[{ }^{\circ} \mathrm{C}\right]}\end{array}$ & $\begin{array}{c}\mathrm{Z2} \mathrm{UHI} \\
{\left[{ }^{\circ} \mathrm{C}\right]}\end{array}$ & $\begin{array}{c}\mathrm{Z3} \mathrm{UHI} \\
{\left[{ }^{\circ} \mathrm{C}\right]}\end{array}$ & $\begin{array}{c}\mathrm{Z4} \mathrm{UHI} \\
{\left[{ }^{\circ} \mathrm{C}\right]}\end{array}$ & $\begin{array}{c}\mathrm{Z} 5 \mathrm{UHI} \\
{\left[{ }^{\circ} \mathrm{C}\right]}\end{array}$ & $\begin{array}{c}\mathrm{Z} 6 \mathrm{UHI} \\
{\left[{ }^{\circ} \mathrm{C}\right]}\end{array}$ \\
\hline$>2$ & 1194 & 674 & 827 & 1168 & 1508 & 571 \\
\hline$>3$ & 603 & 220 & 352 & 477 & 1011 & 202 \\
\hline$>4$ & 243 & 69 & 135 & 129 & 555 & 59 \\
\hline$>5$ & 85 & 14 & 41 & 20 & 290 & 8 \\
\hline
\end{tabular}

Table 4. HOURS OCCURRENCE OF AIR TEMPERATURES FOR THE MONITORED ZONES

\begin{tabular}{|c|c|c|c|c|c|c|c|}
\hline $\begin{array}{c}\text { Temp. } \\
{\left[{ }^{\circ} \mathrm{C}\right]}\end{array}$ & $\begin{array}{c}\mathrm{Z1} \\
\text { hours }\end{array}$ & $\begin{array}{c}\mathrm{Z2} \\
\text { hours }\end{array}$ & $\begin{array}{c}\mathrm{Z} 3 \\
\text { hours }\end{array}$ & $\begin{array}{c}\mathrm{Z4} \\
\text { hours }\end{array}$ & $\begin{array}{c}\mathrm{Z} 5 \\
\text { hours }\end{array}$ & $\begin{array}{c}\mathrm{Z} 6 \\
\text { hours }\end{array}$ & $\begin{array}{c}\text { Ref } \\
\text { hours }\end{array}$ \\
\hline$<16$ & 0 & 4 & 2 & 0 & 0 & 3 & 52 \\
\hline$<18$ & 18 & 50 & 23 & 15 & 6 & 31 & 205 \\
\hline$<20$ & 123 & 234 & 156 & 141 & 68 & 226 & 545 \\
\hline
\end{tabular}

The results in Table IV present the hours during which temperatures fall below some reference values. It can be noted that practically the temperature never drops down $16^{\circ} \mathrm{C}$ in the city, while this is verified for more than 50 hours in the reference station. The number of hours in which temperature is below $18{ }^{\circ} \mathrm{C}$ ranges between 6 and 50 (average 23.8) within the city; this value exceeds 200 in the ENEA station. It is also worth noting that high variable results can be observed within the city stations; the differences are not directly connected to the distance from the city centre since a more complex mechanism emerges depending on the density of the built environment and the presence of green areas affecting the zone thermal conditions.

\section{B. Energy and thermal performance of the reference building}

Figure 4 presents the net energy cooling demand (in $\mathrm{kWh}$ ) of the reference building, during the monitoring period and for the six zones plus the extra urban station. The figure reports the results for the insulated and not insulated configurations. As expected, the energy demands are in line with the data observed for the outdoor temperatures. It is also worth noting that for all the city zones the energy demand decreases as an effect of the thermal insulation, while the contrary applies to the reference station. The phenomenon mainly depends on the effect of the insulation which counters the thermal discharge of the building structure when the night temperatures significantly drop. It is calculated that the extra cooling demand normalised respect to the net floor area is about 10 $\mathrm{kWh} / \mathrm{m} 2$, while in the city it ranges between 13 and 18 $\mathrm{kWh} / \mathrm{m} 2$. The impact on the urban temperatures can be also inferred from figure 5 , where the relative increase of the cooling demand respect to the reference station is depicted for the 6 city zones. The increase for the not insulated configurations ranges between $50 \%$ (Z2 and Z6) and 100\% in Z5. The variations are smaller for the insulated configurations, since all the energy performances improve when considering the buildings within an urban context, while the reference station building shows an increase of the cooling demand. The curve, moreover, shows a more flat trend: the energy penalties are about $50 \%$ in $\mathrm{Z5}$, which is confirmed to be the hottest zone, and the global variation is between 24 and $37 \%$ for the other five zones.

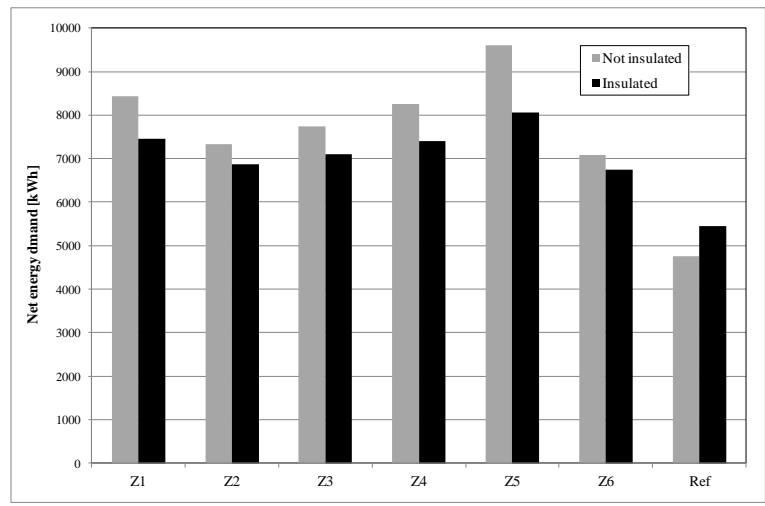

Fig .4. Net energy cooling demand of the reference building in the six monitored zones and for the reference station

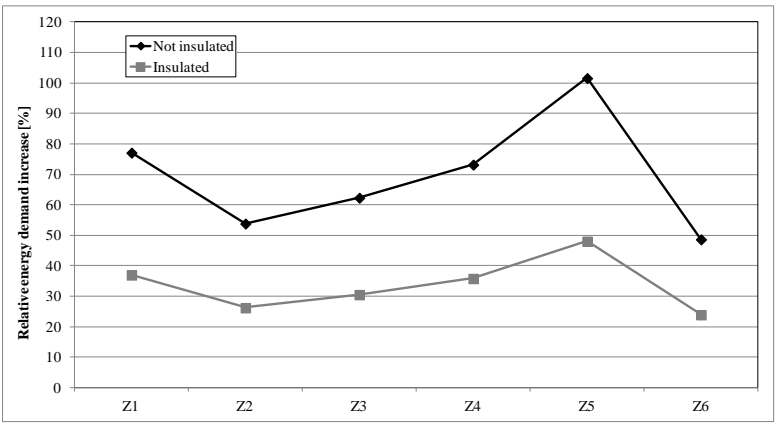

Fig .5. Relative increase of the net cooling energy demand of the building located in the six zones respect to the reference station cooling demand

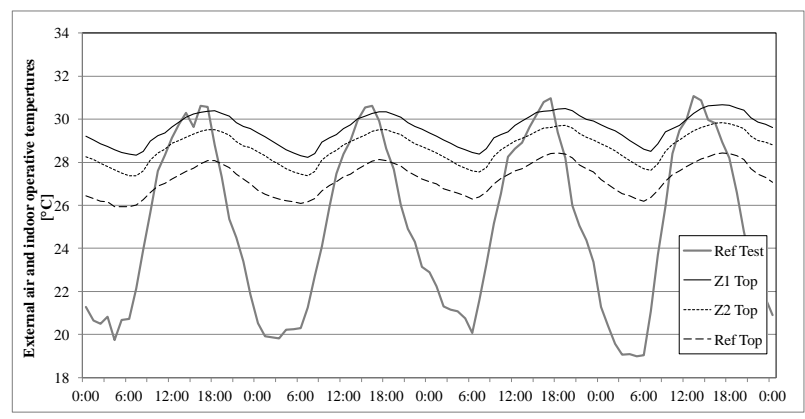

Fig .6. Evolution of ambient air and indoor operative temperature in selected zones 
The calculation also allows highlighting the effect of the urban temperature on the not cooled building based on the fluctuation of the operative temperature in a selected apartment of the block. As an example, four typical August days results are shown in figure 6 where external air in the reference zone and the operative temperatures in $\mathrm{Z} 1, \mathrm{Z} 2$ and reference zone are plotted for the not insulated building. The operative temperature in the reference zone remains below $28^{\circ} \mathrm{C}$ as a peak with the adopted building configuration, which is in line with the comfort expectations according to the adaptive methods. Z1 building is more critical since the operative temperature remains above $30^{\circ} \mathrm{C}$ from 6 to 9 hours per day and it never goes below $28.2^{\circ} \mathrm{C}$. Z2 building shows a less intense thermal stress: the operative temperature remains always lower than $29.5^{\circ} \mathrm{C}$ and drops below $28^{\circ} \mathrm{C}$ at night-time.

Data in Table $\mathrm{V}$ provide aggregate information about the buildings thermal response during the whole period. The average temperature for the reference station is $25.6{ }^{\circ} \mathrm{C}$, in line with thermal comfort expectations. Z1 and Z5 present average operative temperatures higher than $28{ }^{\circ} \mathrm{C}$, while operative temperatures vary between 27.1 and $27.8^{\circ} \mathrm{C}$ for the remaining four zones. Z5 building operative temperature is $3.2^{\circ} \mathrm{C}$ higher with respect to the reference station building, while it varies between 2.2$2.4{ }^{\circ} \mathrm{C}$ for $\mathrm{Z} 1$ and $\mathrm{Z} 4$. It remains below $2{ }^{\circ} \mathrm{C}$ for the remaining zones. The thermal insulation causes an increase average temperature increasing of $0.8-0.9^{\circ} \mathrm{C}$ for all the selected zones. This implies that difference regarding the reference station buildings remains basically equal to that found for the not insulated case.

Results can also be observed in terms of cumulative distribution of the operative temperatures in the buildings for the different city zones. Table VI shows these results for the not insulated configuration. The reference zone results are not reported since an operative temperature higher than $28{ }^{\circ} \mathrm{C}$ is reached only in 100 hours and it never reaches $29^{\circ} \mathrm{C}$, implying that thermal comfort conditions are assured in most of the monitored period. Different results are achieved for the other zones. The most critical one is $Z 5$ where the temperature is higher than $30^{\circ} \mathrm{C}$ for the $20 \%$ of the period and in Z1 where this happens in the $10 \%$ of the calculated hours. Temperatures above $28^{\circ} \mathrm{Care}$ reached in a percentage of the period ranging between 28 and $68 \%$, so the overheating risk applies to all the monitored zones. Anyway, extreme phenomena can be expected only for a short period ( 1 to $6 \%$ of the calculated hours) in zones Z2, Z3, Z4 and Z6.

Table 5. AVERAGE OPERATIVE TEMPERATURE AND DIFFERENCES VERSUS THE REFERENCE STATION BUILDING

\begin{tabular}{|c|c|c|c|c|c|c|c|}
\hline $\begin{array}{c}\text { Tm_op } \\
{\left[{ }^{\circ} \mathrm{C}\right]}\end{array}$ & $\begin{array}{c}\text { Z1 } \\
\text { hours }\end{array}$ & $\begin{array}{c}\text { Z2 } \\
\text { hours }\end{array}$ & $\begin{array}{c}\text { Z3 } \\
\text { hours }\end{array}$ & $\begin{array}{c}\text { Z4 } \\
\text { hours }\end{array}$ & $\begin{array}{c}\text { Z5 } \\
\text { hours }\end{array}$ & $\begin{array}{c}\text { Z6 } \\
\text { hours }\end{array}$ & $\begin{array}{c}\text { Ref } \\
\text { hours }\end{array}$ \\
\hline NIns & 28.0 & 27.2 & 27.5 & 27.8 & 28.8 & 27.1 & 25.6 \\
\hline$\Delta$ NIns & 2.4 & 1.7 & 1.9 & 2.2 & 3.2 & 1.5 & --- \\
\hline Ins & 28.9 & 28.1 & 28.4 & 28.6 & 29.6 & 28.0 & 26.4 \\
\hline$\Delta$ Ins & 2.5 & 1.7 & 2.0 & 2.2 & 3.2 & 1.6 & -- \\
\hline
\end{tabular}

Table 6. HOURS OF OPERATIVE TEMPERATURE IN THE CITY BUILDINGS

\begin{tabular}{|c|c|c|c|c|c|c|}
\hline $\begin{array}{c}\text { Temp. } \\
{\left[{ }^{\circ} \mathrm{C}\right]}\end{array}$ & $\begin{array}{c}\mathrm{Z1} \mathrm{UHI} \\
{\left[{ }^{\circ} \mathrm{C}\right]}\end{array}$ & $\begin{array}{c}\mathrm{Z2} \mathrm{UHI} \\
{\left[{ }^{\circ} \mathrm{C}\right]}\end{array}$ & $\begin{array}{c}\mathrm{Z3} \mathrm{UHI} \\
{\left[{ }^{\circ} \mathrm{C}\right]}\end{array}$ & $\begin{array}{c}\mathrm{Z4} \mathrm{UHI} \\
{\left[{ }^{\circ} \mathrm{C}\right]}\end{array}$ & $\begin{array}{c}\mathrm{Z5} \mathrm{UHI} \\
{\left[{ }^{\circ} \mathrm{C}\right]}\end{array}$ & $\begin{array}{c}\mathrm{Z6} \mathrm{UHI} \\
{\left[{ }^{\circ} \mathrm{C}\right]}\end{array}$ \\
\hline$>28$ & 1020 & 599 & 750 & 897 & 1331 & 546 \\
\hline$>29$ & 530 & 218 & 304 & 377 & 898 & 189 \\
\hline$>30$ & 193 & 30 & 76 & 119 & 412 & 25 \\
\hline$>31$ & 33 & 0 & 0 & 4 & 133 & 0 \\
\hline
\end{tabular}

Results provided by the simulation carried out on the insulated building show an increase of overheating risk. Hours with operative temperature above $30^{\circ} \mathrm{C}$ double in Z1 and Z5. This threshold value is not completely negligible for the remaining monitored zones, since an occurrence between 10 and $18 \%$ of the period is calculated.

\section{DISCUSSION AND CONCLUSIONS}

This paper presents preliminary results of a study aimed at assessing the impact of the urban thermal climate on the energy and thermal response of reference buildings during the cooling season in the city of Rome, Italy. The study is focused on a limited observation period, since the monitoring activity refers to the initial phase of the campaign that started in July 2014, and is still on-going. Air temperature and relative humidity were continuously measured in six districts, as well as in an extra urban reference station.

The results show that city of Rome is affected by a significant increase of the air temperature, namely Urban Heat Island phenomenon. UHI intensities range between $6(\mathrm{ZG})$ and $9.9^{\circ} \mathrm{C}(\mathrm{Z5})$, while monthly $\mathrm{UHI}$ ranges between $1.3^{\circ} \mathrm{C}$ in $\mathrm{Z6}$ in September and $3.4^{\circ} \mathrm{C}$ in $\mathrm{Z} 5$ in August. Referring to the whole period, $\mathrm{UHI}$ varies between $1.5^{\circ} \mathrm{C}(\mathrm{Z6})$ and $3.2^{\circ} \mathrm{C}(\mathrm{Z5})$. Energy analysis shows a significant increase of the cooling energy demand respect to the reference station out of the city. Relative increase of the demand ranges between 50 and $100 \%$ for the not 
insulated building, while the increase is almost reduced by half for the insulated configuration. In terms of averaged operative temperature values over the whole observation period, the increase for the reference station is between $1.5^{\circ} \mathrm{C}$ and $3.2^{\circ} \mathrm{C}$. The registered values also show an increase of $0.8-0.9^{\circ} \mathrm{C}$ for the insulated configuration with respect to the not insulated one.The study shows how severe the urban climate is in the city of Rome and how risky it could be for building occupants during hot periods in summer. City cooling strategies should be implemented to mitigate as much as possible the thermal conditions. Some areas could benefit of extended vegetation to take advantage of evaporative cooling (Z2, Z4, Z6); some other zones have an urban texture that does not allow significant modifications, in this case a conscious building design and urban materials with higher albedo values should be used to control temperatures. During night time, passive and ventilated cooling techniques should be implemented. The city monitoring campaign is still on-going. Next steps will include both winter and summer analyses with a more extended data set, based on the continuous monitoring of air temperature and relative humidity.

\section{REFERENCES}

[1] IPCC, Climate Change 2007: Synthesis Report. Contribution of Working Groups I, II and III to the Fourth Assessment Report of the Intergovernmental Panel on Climate Change [Core Writing Team, R. K. Pachauri, and A. Reisinger, (eds.)], IPCC, Geneva, Switzerland, $104 \mathrm{pp}$.

[2] IPCC, 2014: Summary for Policymakers. In: Climate Change 2014: Mitigation of Climate Change. Contribution of Working Group III to the Fifth Assessment Report of the Intergovernmental Panel on Climate Change [Edenhofer, O., R. Pichs-Madruga, Y. Sokona, E. Farahani, S. Kadner, K. Seyboth, A. Adler, I. Baum, S. Brunner, P. Eickemeier, B. Kriemann, J. Savolainen, S. Schlömer, C. von Stechow, T. Zwickel and J. C. Minx (eds.) Cambridge University Press, Cambridge, United Kingdom and New York, NY, USA.

[3] Plan Bleu, "Climate change and energy in the Mediterranean Plan Bleu - Regional Activity Center, Sophia Antipolis, July 2008.
[4] T. R. Oke, G. T. Johnson, D. G. Steyn, and I. D. Watson, "Simulation of surface urban heat islands under "' 'ideal' conditions at night: Part 2. Diagnosis of causation, Boundary Layer Meteorol. 56, 1991,pp. 339-358.

[5] M. Santamouris (Ed.), Energy and Climate in the Urban Built Environment, London, James and James Science Publishers, 2001.

[6] D. Stewart, "A systematic review and scientific critique of methodology in modern urban heat island literature", International Journal of Climatology, Special Issue: ICUC-7 Urban Climate Meeting 2011, 31(2), pp. 200-217.

[7] D. K. Papanastasiou, and C. Kittas, "Maximum urban heat island intensity in a medium-sized coastal Mediterranean city," Theoretical and Applied Climatology, 107 (3-4) , 2012, pp. 407416.

[8] P. Coseo, and L. Larsen, "How factors of land use/land cover, building configuration, and adjacent heat sources and sinks explain urban heat islands in Chicago", Landscape and Urban Planning, Vol. 125, May 2014, pp. 117-129.

[9] M. Kolokotroni, X. Ren, M. Davies, and A. Mavrogianni, "London's urban heat island: impact on current and future energy consumption in office buildings", Energy and Buildings, 47, 2012, pp. 302-311.

[10] H. Akbari, and S. Konopacki, "Energy effects of heat-island reduction strategies in Toronto, Canada", Energy and Buildings, 29, 2004, pp. 191-210.

[11] M. Santamouris, N. Papanikolaou, I. Livada, I. Koronakis, C. Georgakis, A. Argiriou, and D. N. Assimakopoulos, "On the impact of urban climate to the energy consumption of buildings", Solar Energy, 70 (3), 2001, pp. 201-216.

[12] E. Carnielo, and M. Zinzi, "Optical and thermal characterisation of cool asphalts to mitigate urban temperatures and building cooling demand", Building and Environment, 60, 2013, pp. 56-65.

[13] TRNSYS 16; www.trnsys.com. 